\title{
Coolbox Design Modification for Traditional Fishing Vessel Using Sengon Wood Sawdust and Potassium Hydroxide-Soaked Coconut Coir
}

\author{
Ede Mehta Wardhana ${ }^{1}$, Alam Baheramsyah ${ }^{2}$, Hilmy Yassar $^{3}$ \\ (Received: 06 August 2019 / Revised: 02 December 2019 / Accepted: 01 March 2020)
}

\begin{abstract}
- this research modified the coolbox by mixing sengon wood sawdust and potassium hydroxide-soaked cocofiber. By considering its composition, potassium hydroxide content, and soaking duration, this research was done to find the optimum amount of those three variables to make the best insulator. The best insulator was chosen based on its thermal conductivity, density, and economic value, and the easiness in the making. From the experiment, the chosen composition consists of $30 \%$ sengon wood sawdust and $70 \%$ potassium hydroxide-soaked coco fiber with the content of $15 \%$ and soaking duration of 2 hours. With a thermal conductivity of $0,352 \mathrm{~W} / \mathrm{mK}$, a density of $0,303 \mathrm{gram} / \mathrm{cm}^{3}$, and specimen production cost of $\mathrm{Rp607,41}$, this material was used for composition reference in the making of the coolbox. The experiment of the coolbox lasted for 35 hours, with 71 temperature data retrievals. The coolbox experiment used 500-gram tuna fish and 2500 gram ice as cooler. The result showed that the lowest temperature for ice inside the coolbox was $0,3^{\circ} \mathrm{C}$, the lowest temperature of fish was $5^{\circ} \mathrm{C}$, and the lowest temperature in the coolbox chamber is $17^{\circ} \mathrm{C}$. With the ratio of $1: 5$ for fish and ice, the coolbox insulation using sengon wood sawdust and potassium hydroxide-soaked coco fiber was able to maintain the fish temperature below $20^{\circ} \mathrm{C}$ for 27,5 hours. Meanwhile, the styrofoam coolbox was able to maintain fish with the same condition for 35 hours.
\end{abstract}

Keywords — coolbox, coconut coir, potassium hydroxide, sengon wood, thermal conductivity.

\section{INTRODUCTION}

$\mathrm{S}_{1}$ for fish storage. But it turns out that the use of styrofoams is not safe for health and leaves so much waste to the environment, which is so hard to degrade. To reduce the use of styrofoam, it is necessary to have an alternative material as coolbox insulation, which has low thermal conductivity and environmentally friendly to replace the use of styrofoam. One of the solutions is to use natural insulation so the coolboxes will be easily degradable.

This research used sengon wood and coconut coir to replace the styrofoam as insulation. Sengon wood's characteristic is light in its weight and also has low thermal conductivity value up to $0.099 \mathrm{~W} / \mathrm{mK}$ [1-3]. Meanwhile, coconut coir has strong characteristics and low thermal conductivity also, which is up to 0.05 $\mathrm{W} / \mathrm{m}^{\circ} \mathrm{C}$ [4-5], so those components could be a potential insulator to replace the use of styrofoam.

To compete for the low thermal conductivity of styrofoam, a process called alkalization is used to decrease the thermal conductivity of natural fiber. This process removes the content of lignin and oil that covers the outer surface of the fiber. It changes hydrogen bonds in the fiber's structure network, so the surface of the fiber becomes rough. Since coconut fiber has a lignin content of $35 \%-45 \%$ [6], the thermal conductivity could be minimized [7-8]. The alkalization uses alkaline solution such as natrium hydroxide $(\mathrm{NaOH})$, potassium hydroxide $(\mathrm{KOH})$, or it could be lithium hydroxide $(\mathrm{LiOH})$. In this research, the solution used is potassium hydroxide since it is easy to be found and relatively cheap.

$\mathrm{KOH}$ solution makes a reaction with lignin from coconut coir, as shown in Figure 1. The reaction dissociates $\mathrm{KOH}$ into $\mathrm{K}^{+}$and $\mathrm{OH}^{-}$. The $\mathrm{OH}^{-}$ion then reacts with the $\mathrm{H}$ group on lignin and forms water $\left(\mathrm{H}_{2} \mathrm{O}\right)$, which causes the $\mathrm{O}$ group of lignin to become free radical and more reactive to carbon $(\mathrm{C})$ and from an epoxy ring (C-O-C). The result is a series of groups releasing bonds to the $\mathrm{O}$ group and producing two benzene rings. Each ring has an $\mathrm{O}$ group reactive to $\mathrm{K}^{+}$ and then dissolve. Thus, the lignin perishes and the diameter of the coconut fiber shrinks [9-11].

\footnotetext{
${ }^{1}$ Ede Mehta Wardhana, Department of Marine Engineering, Institut Teknologi Sepuluh Nopember, Surabaya 60111, Indonesia, Email : edewardhana123@gmail.com

${ }^{2}$ Alam Baheramsyah, Department of Marine Engineering, Institut Teknologi Sepuluh Nopember, Surabaya 60111, Indonesia, Email: abaheramsyah@gmail.com
}

${ }^{3}$ Hilmy Yassar, Department of Marine Engineering, Institut Teknologi Sepuluh Nopember, Surabaya 60111, Indonesia, Email : hilmyyassar07@gmail.com 


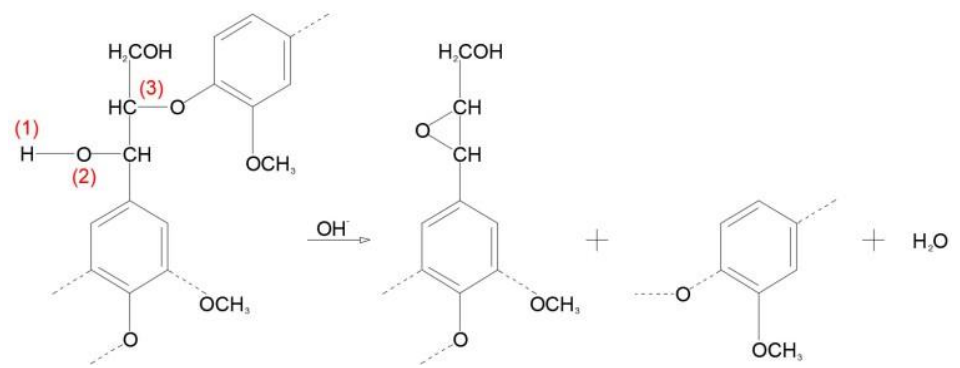

Figure 1. Chemical Reaction of Alkalization Process

\section{METHOD}

\section{A. Specimen Making}

This research used 15 specimens which are different in composition. The purpose of it is to determine the most optimum composition in order to make the best insulator, which has low thermal conductivity, low density, low cost, and is easy to be made. The specimen mass varies in the ratio of $30: 70$; 50:50; 70:30 (Sengon wood: Alkalized coconut fiber). The potassium hydroxide content also varies in $0 \%$ (without immersion), $15 \%$, and $30 \%$, while the soaking duration varies in 1 hour and 2 hours of immersion. The specimens made are shown in Figure 2. Those 15 variant of a specimen are:

1. Specimen 1: 70\% Sengon, 30\% Coconut Fiber

2. Specimen 2: $70 \%$ Sengon, $30 \%$ Coconut Coir, with a soaking of $15 \% \mathrm{KOH}$ for 1 hour

3. Specimen 3: $70 \%$ Sengon, 30\% Coconut Coir, with a soaking of $15 \% \mathrm{KOH}$ for 2 hours

4. Specimen 4: $70 \%$ Sengon, $30 \%$ Coconut Coir, with soaking of $30 \% \mathrm{KOH}$ for 1 hour

5. Specimen 5: $70 \%$ Sengon, $30 \%$ Coconut Coir, with a soaking of $30 \% \mathrm{KOH}$ for 2 hours

6. Specimen 6: 50\% Sengon, 50\% Coconut Fiber

7. Specimen 7: 50\% Sengon, 50\% Coconut Coir, with a soaking of $15 \% \mathrm{KOH}$ for 1 hour

8. Specimen 8: $50 \%$ Sengon, $50 \%$ Coconut Coir, with a soaking of $15 \% \mathrm{KOH}$ for 2 hours

9. Specimen 9: 50\% Sengon, 50\% Coconut Coir, with a soaking of $30 \% \mathrm{KOH}$ for 1 hour

10. Specimen 10: 50\% Sengon, 50\% Coconut Coir, with a soaking of $30 \% \mathrm{KOH}$ for 2 hours

11. Specimen 11: 30\% Sengon, 70\% Coconut Fiber

12. Specimen 12: $30 \%$ Sengon, $70 \%$ Coconut Coir, with a soaking of $15 \% \mathrm{KOH}$ for 1 hour

13. Specimen 13: $30 \%$ Sengon, 70\% Coconut Coir, with a soaking of $15 \% \mathrm{KOH}$ for 2 hours

14. Specimen 14: $30 \%$ Sengon, 70\% Coconut Coir, with a soaking of $30 \% \mathrm{KOH}$ for 1 hour

15. Specimen 15: 30\% Sengon, 70\% Coconut Coir, with a soaking of $30 \% \mathrm{KOH}$ for 2 hours

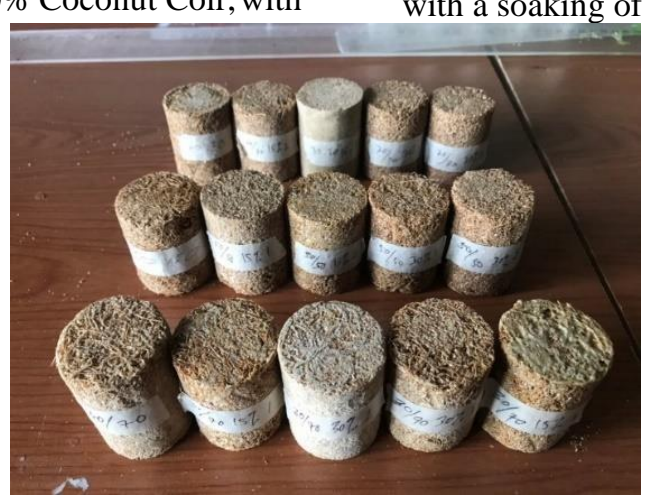

Figure 2. Specimens

\section{B. Specimen Testing}

1. Density Test

The specimen for density measurement has a form of a cylinder with a diameter of $3.8 \mathrm{~cm}$ and a height of $5 \mathrm{~cm}$. Mass measurements were made by weighing the specimens using the scales. Then do the density calculation using equation (1).

$$
\rho=\frac{m}{V}
$$

Where :

$\rho=$ density $\left(\mathrm{gr} / \mathrm{cm}^{3}\right)$

$\mathrm{m}=$ mass of specimen $(\mathrm{gr})$

$\mathrm{V}=$ volume of specimen $\left(\mathrm{cm}^{3}\right)$
2. Thermal Conductivity Test

Thermal conductivity test in this thesis is based on ASTM E 1225 - Standard Test Method for Thermal Conductivity of Solids by Means of the Guarded Comparative-Longitudinal Heat Flow Technique. The specimen was inserted between two similar loads of known thermal properties material (copper).

The thermal conductivity testing is shown in Figure 3. A temperature gradient is set in the test stack, and the heat loss is minimized by using an insulator that has approximately the same temperature gradient.

Under equilibrium conditions, the thermal conductivity is derived from the temperature gradient measured in each specimen and the thermal conductivity of the 
Reference material (conductor).

The first step is to calculate the thermal conductivity value of the thermal conductor (copper) based on the thermal conductivity value of copper, as seen in Table 1.

Since the thermal conductivity of copper obtained, the calorific value of copper can be calculated using equation (2)

$$
Q_{t}=\frac{K_{t} \times A_{t} \times \Delta_{t}}{L_{t}}
$$

Where :

$Q_{\mathrm{t}}=$ Heat in Cooper $(\mathrm{W})$

$\mathrm{K}_{\mathrm{t}}=$ Thermal Conductivity of cooper

$(\mathrm{W} / \mathrm{mK}) \mathrm{A}_{\mathrm{t}}=$ Area of Cooper Surface $\left(\mathrm{m}^{2}\right)$

$\Delta T t=$ Temperature differences $\left({ }^{\circ} \mathrm{C}\right)$

$\mathrm{L}_{\mathrm{t}}=$ Length of cooper $(\mathrm{m})$
In this experiment, it is assumed that the system is in steady-state, so, the amount of incoming heat (heat in copper) is equal to the amount of heat that comes out (heat on the specimen).

$$
\begin{gathered}
Q_{\text {in }}=Q_{\text {out }} \\
Q_{\text {cooper }}=Q_{\text {specimen }}
\end{gathered}
$$

Since the amount of incoming heat $(\mathrm{Qt})$ can be calculated using equation (2), the thermal conductivity of the specimen can be calculated using equation (3)

$$
K_{s p}=\frac{Q_{s p} \times L_{s p}}{A_{s p} \times \Delta T_{s p}}
$$

Where :

$Q_{\text {sp }}=$ Heat in Cooper (W)

$\mathrm{K}_{\mathrm{sp}}=$ Thermal Conductivity of specimen $(\mathrm{W} / \mathrm{mK})$

$A_{\mathrm{sp}}=$ Area of Specimen Surface $\left(\mathrm{m}^{2}\right)$

$\Delta T_{\mathrm{sp}}=$ Temperature differences $\left({ }^{\circ} \mathrm{C}\right)$

$\mathrm{L}_{\mathrm{sp}}=$ Length of specimen $(\mathrm{m})$

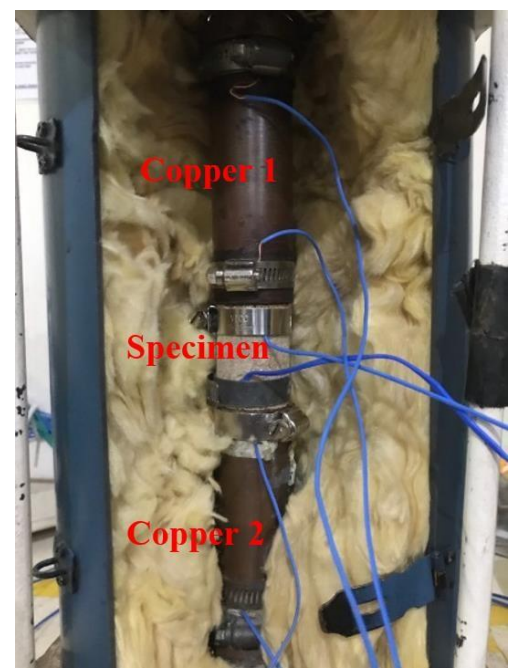

Figure 3. Thermal Conductivity Test

TABLE 1.

THERMAL CONDUCTIVITY OF COPPER

\begin{tabular}{lccc}
\hline \multirow{2}{*}{ Material } & \multicolumn{3}{c}{ Thermal Conductivity $(\mathrm{W} / \mathrm{mK})$} \\
\cline { 2 - 4 } & $300 \mathrm{~K}$ & $400 \mathrm{~K}$ & $500 \mathrm{~K}$ \\
\hline Pure Cooper & 401 & 393 & 388 \\
\hline
\end{tabular}

\section{Specimen Selection}

From a total of 15 specimens, one specimen will be selected based on the value of thermal conductivity, density, production cost, and the difficulty of specimen making. Each point has a percentage value for the total score in order to choose the best specimen. Those percentages are $50 \%$ for the thermal conductivity of specimens, $20 \%$ for the density of specimens, $25 \%$ for specimen cost, and $5 \%$ for the availability of specimen material. The specimen with the highest score will be chosen as coolbox material.

\section{Coolbox Making}

The best insulation material composition of sengon wood sawdust and potassium hydroxide-soaked coconut coir will be used for the base material of composite coolbox insulation. Coolbox that will be made has dimensions, as shown in Figure $\mathbf{4}$ and $\mathrm{h}$. For the coolbox wall, resin and plywood are used as insulation coatings. The plywood (plywood) will be the first layer in insulation, and the resin will be the outermost layer of the coolbox wall. The thickness of the resin used is $1 \mathrm{~mm}$ and $4 \mathrm{~mm}$ plywood, while the insulation is as thick as $20 \mathrm{~mm}$. The layers of the coolbox wall shown in Figure 5. 

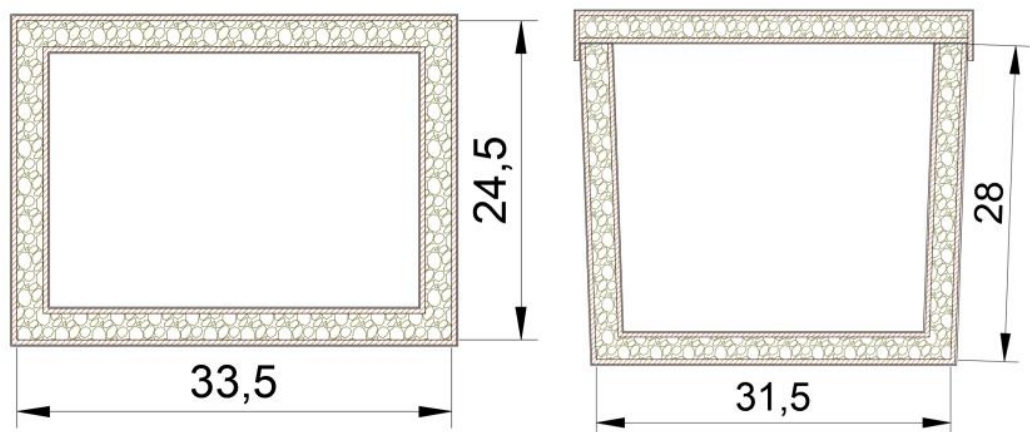

Figure 4. Coolbox Dimension
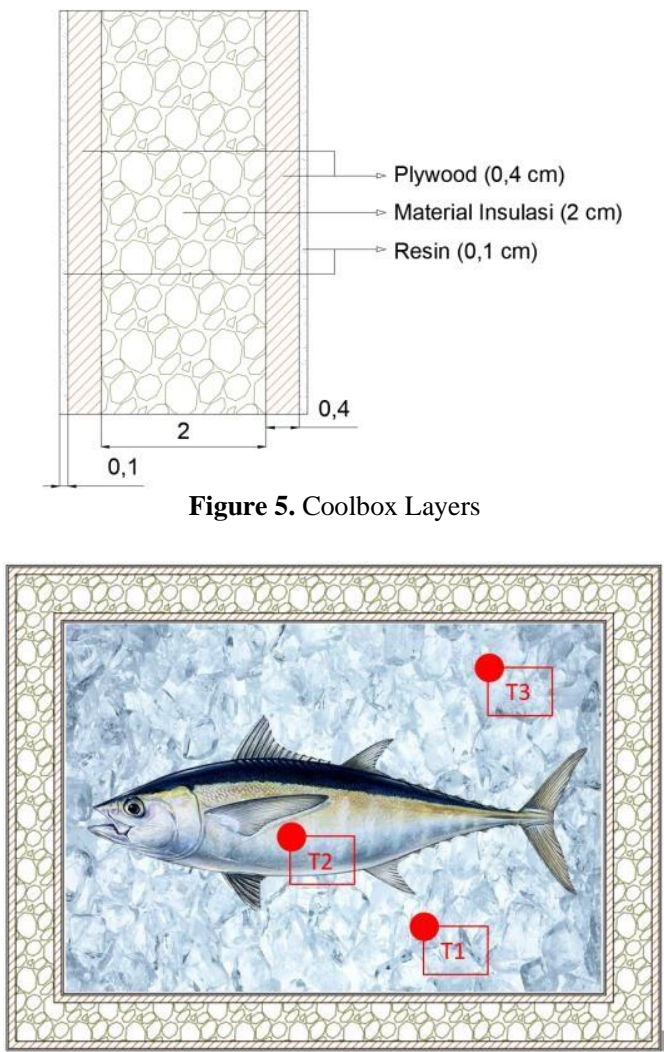

Figure 6. Coolbox Test Diagram

\section{E. Full-Scale Experiment}

The experiment was done by comparing the performance between coolbox with sengon wood insulation and straw and coolbox made from styrofoam. In styrofoam-based coolbox will be treated the same with coolbox with sengon wood insulation and, that is, coat the coolbox with plywood and resin. Sea fish is used as a cooling load, which is a type of tuna fish with a mass of 500 grams and ice flakes with a mass of 2.5 kilograms. Two observations will be made:

1. Cooling time

Conducted observations of the coolbox containing fish and ice wet until the coolbox space reach $20^{\circ} \mathrm{C}$. Temperature $20{ }^{\circ} \mathrm{C}$ is used because, at this temperature, the fish can be said in fresh condition.

2. The lowest temperature achieved.

In this experiment conducted the lowest temperature observations that can be achieved coolbox within 35 hours. Data retrievals are done every 30 minutes. With observation point as shown in Figure 6 which are:

- Point 1 , located beneath the surface of the ice

- Point 2, inside the fish body

- Point 3, located in the coolbox space

\section{F. Data Analysis}

The data achieved from the coolbox experiment is analyzed based on the maximum cooling time, and the lowest temperature achieved during the cooling process from both modified coolboxes and styrofoam coolboxes. The maximum cooling time is the analysis of fish preservation when the temperature is below 20 ${ }^{\circ} \mathrm{C}$. While the lowest temperature analysis is the analysis of the ability of coolboxes in order to achieve a temperature in that three-points as low as they can, these analyses will compare which coolbox is the most suitable coolbox for fish storage. 


\section{RESULTS AND DISCUSSION}

\section{A. Chemical Treatment and Test Result}

The results from the immersion of potassium hydroxide are shown in Figure 7. Those four fibers have differences, both physically and chemically. Of the four variables, the most visible thing is the difference in color where the fiber without chemical treatment has a bright color, while fiber with chemical treatment has a color that tends to be darker. The greater the percentage of $\mathrm{KOH}$, the darker the color of the fiber, and vice versa. Besides that, the fiber diameter had also decreased because

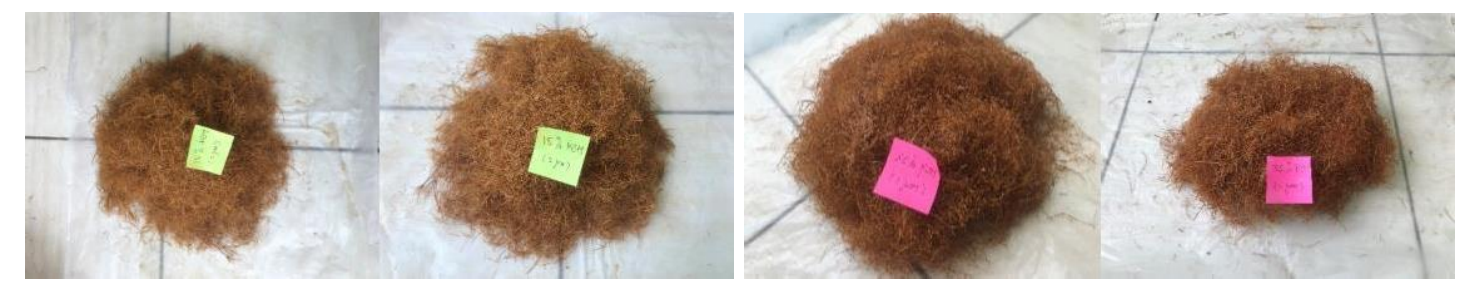

Figure 7. $\mathrm{KOH}$-soaked Coconut Coir

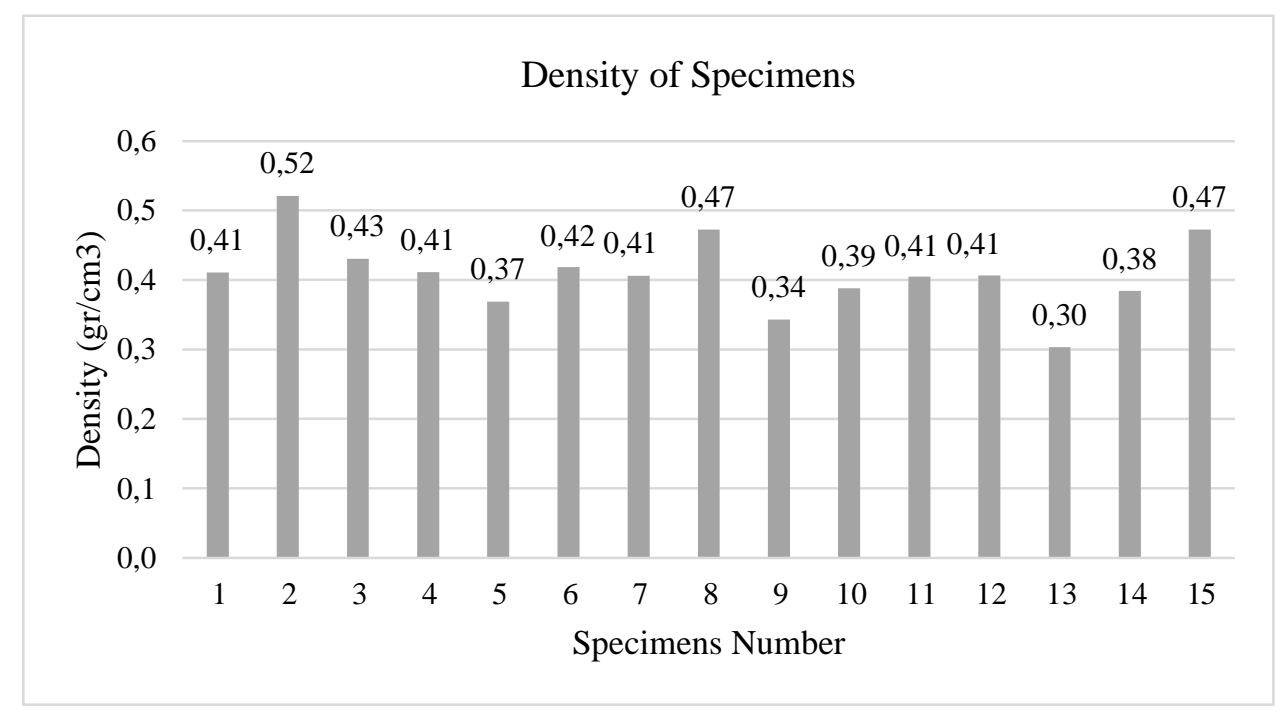

Figure 8. Density of Specimens

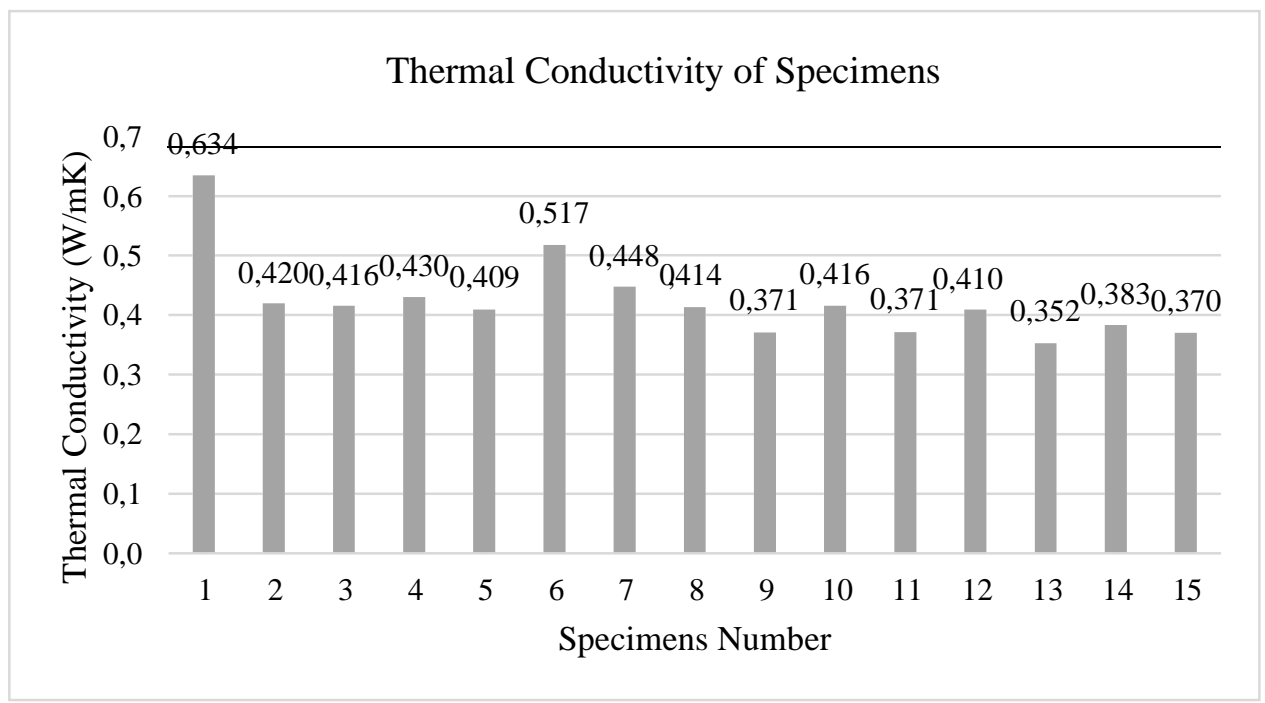

Figure 9. Thermal Conductivity of Specimens of the alkalization process. Theoretically, the more alkali content, the more lignin of the fiber will vanish. But too much $\mathrm{KOH}$ content could also

The density of specimens was calculated by dividing mass by its volume. From the 15 specimens, the lowest density achieved was on the $13^{\text {th }}$ specimen, which has a density of 0.303 $\mathrm{gram} / \mathrm{cm}^{3}$. The density calculation result is shown in Figure 8. For the thermal conductivity, the lowest value achieved was also on the $13^{\text {th }}$ specimen which has a thermal conductivity value of

$0.352 \mathrm{~W} / \mathrm{mK}$. The overall results of thermal conductivity are shown in Figure 9. 
International Journal of Marine Engineering Innovation and Research, Vol. 5(1), Mar. 2020. 44-52

\section{B. Specimen Selection}

Specimens are selected based on the score of specimens, $50 \%$ for the thermal conductivity, $20 \%$ for the density, $25 \%$ for specimen cost, and $5 \%$ for the availability of material. The highest score was achieved by specimen number 13 , with a score of 0.877 . The value of thermal conductivity was $0.352 \mathrm{~W} / \mathrm{mK}$, and the density was $0.303 \mathrm{gr} / \mathrm{cm}^{3}$, specimen cost was
Rp607,00 and the easiness of manufacture score was 0.8 . This specimen was chosen as coolbox insulation for the next test and had a composition of $30 \%$ sengon wood sawdust and $70 \%$ coconut coir fiber with 2 -hour immersion of $15 \%$ potassium hydroxide. The result of the score calculation can be seen in Table 2 , and the chosen coolbox material can be seen in Table 3 .

TABLE 2.

SPECIMEN SELECTION

\begin{tabular}{ccccccc}
\hline \multirow{2}{*}{\begin{tabular}{c} 
Number $\begin{array}{c}\text { Score } \\
\text { of } \\
\text { Specimen }\end{array}$ \\
\cline { 2 - 5 }
\end{tabular}} & $\begin{array}{c}\text { Thermal } \\
\text { Conductivity }\end{array}$ & Density & $\begin{array}{c}\text { Production } \\
\text { Cost }\end{array}$ & $\begin{array}{c}\text { Availability } \\
\text { of material }\end{array}$ & Total Score & Rank \\
\hline 1 & 0.50 & 0.10 & 0.03 & 0.043 & 0.394 & 13 \\
\hline 2 & 1.00 & 0.20 & 0.05 & 0.038 & 0.623 & 15 \\
\hline 3 & 1.50 & 0.30 & 0.08 & 0.040 & 0.716 & 5 \\
\hline 4 & 2.00 & 0.40 & 0.10 & 0.038 & 0.647 & 12 \\
\hline 5 & 2.50 & 0.50 & 0.13 & 0.040 & 0.726 & 4 \\
\hline 6 & 3.00 & 0.60 & 0.15 & 0.043 & 0.589 & 6 \\
\hline 7 & 3.50 & 0.70 & 0.18 & 0.038 & 0.645 & 10 \\
\hline 8 & 4.00 & 0.80 & 0.20 & 0.040 & 0.647 & 8 \\
\hline 9 & 4.50 & 0.90 & 0.23 & 0.038 & 0.742 & 3 \\
\hline 10 & 5.00 & 1.00 & 0.25 & 0.040 & 0.624 & 7 \\
\hline 11 & 5.50 & 1.10 & 0.28 & 0.043 & 0.857 & 2 \\
\hline 12 & 6.00 & 1.20 & 0.30 & 0.038 & 0.678 & 9 \\
\hline 13 & 6.50 & 1.30 & 0.33 & 0.040 & 0.877 & 1 \\
\hline 14 & 7.00 & 1.40 & 0.35 & 0.038 & 0.608 & 11 \\
\hline 15 & 7.50 & 1.50 & 0.38 & 0.040 & 0.554 & 14 \\
\hline
\end{tabular}

TABLE 3.

SPECIFICATION OF COOLBOX

\begin{tabular}{|c|c|c|c|}
\hline \multirow[t]{2}{*}{ Part } & \multicolumn{3}{|c|}{ Specification } \\
\hline & Length (m) & Width (m) & Height (m) \\
\hline Lid & 0.335 & 0.245 & \multirow{2}{*}{0.28} \\
\hline Body & 0.315 & 0.225 & \\
\hline \multirow{10}{*}{ Insulation } & \multicolumn{3}{|c|}{ Specification } \\
\hline & Sengon Wood & 30 & $\%$ \\
\hline & Coconut Coir & 70 & $\%$ \\
\hline & $\mathrm{KOH}$ & 15 & $\%$ \\
\hline & Immersion & 2 & hours \\
\hline & Density & 0.3035 & $\mathrm{~g} / \mathrm{cm}^{3}$ \\
\hline & $\begin{array}{l}\text { Thermal } \\
\text { Conductivity }\end{array}$ & 0.3523 & $\mathrm{~W} / \mathrm{mK}$ \\
\hline & Polyurethane & 0.1275 & $\mathrm{gr} / \mathrm{cm}^{3}$ \\
\hline & Thickness & 2 & $\mathrm{~cm}$ \\
\hline & Volume & 8478.84 & $\mathrm{~cm}^{3}$ \\
\hline \multirow{2}{*}{ Layer } & Plywood & 4 & $\mathrm{~mm}$ \\
\hline & Resin & 1 & $\mathrm{~cm}$ \\
\hline
\end{tabular}




\section{Coolbox Testing Result}

The experiment is done by filling the coolbox with wet ice and tuna fish. The proportion of fish and ice used in this experiment was 1: 5 , where the fish mass was 500 grams and 2500 grams for the ice. With this comparison, the whole body of the fish has not been covered with wet ice-three temperature observation points placed in the coolbox. Point 1 (T1) was at the bottom of the coolbox, used to measure the temperature of the ice inside the coolbox, point 2 (T2) was in the fish body by piercing the fish and inserting the thermocouple inside, and point 3 (T3) was in the coolbox ceiling, used to set the coolbox room temperature.

Figure 9. shows the temperature of ice or T1 in the composite coolbox was lower than the ice temperature in the styrofoam coolbox starting from the first data collection until the 6th data collection or at 150 minutes mark with a minimum temperature of $0.3{ }^{\circ} \mathrm{C}$. After that, the ice temperature on the Styrofoam coolbox was below the temperature of the ice inside the composite coolbox. The second coolbox ice temperature was then relatively stable in the range of $0.2{ }^{\circ} \mathrm{C}$ to $0.4{ }^{\circ} \mathrm{C}$ until the 25 th data collection or at 720 minutes mark. Then the temperature rose after that, where the temperature rise occurred 2.5 hours after the increase in ambient temperature at a 570-minute mark or at $06.00 \mathrm{WIB}$, that was when the sun rose and started to be bright at that time. Furthermore, the increase of ice temperature inside composite coolbox slowed at 1500 minutes mark in tandem with the drop in ambient temperature and reached a temperature of $24{ }^{\circ} \mathrm{C}$ in the last data retrieval that was at 2100 minutes mark. Whereas the styrofoam coolbox began to increase in 1470 minutes mark, then reached a temperature of $18.2{ }^{\circ} \mathrm{C}$ at the end of the data retrieval.

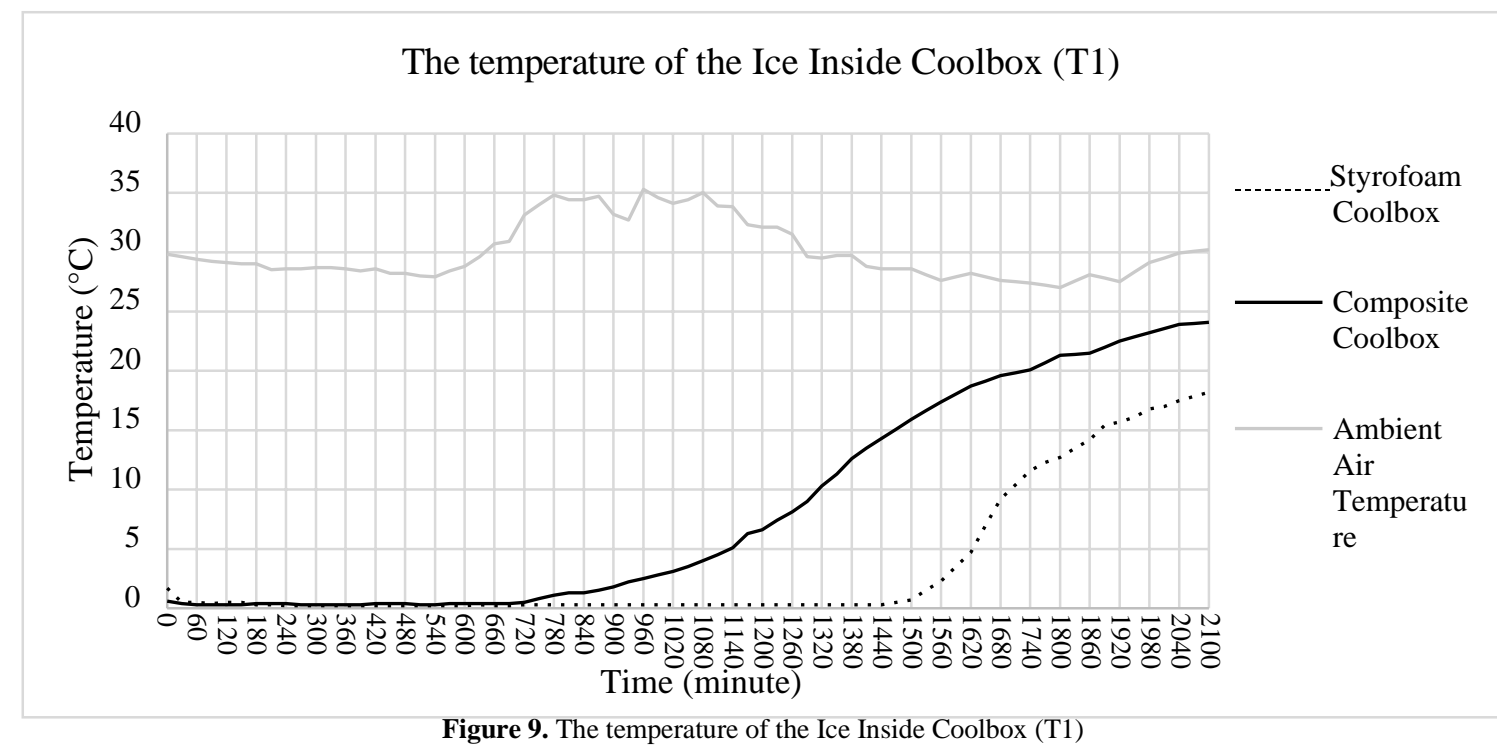

Figure 10. shows that the minimum temperature of fish (T2) that could be achieved by the composite coolbox for 2 hours was $5{ }^{\circ} \mathrm{C}$. The low temperature could be achieved by the composite coolbox for 1.5 hours from 240 to 300 minutes mark. While the minimum temperature that could be achieved by styrofoam coolbox was $4{ }^{\circ} \mathrm{C}$ for 2 hours at 240 to 360 minutes mark. Both of coolboxes the temperature rose slowly and at 960 minute mark the increase in temperature of the fish in the composite coolbox got faster while the temperature of the fish in the styrofoam coolbox decreased to $0.5{ }^{\circ} \mathrm{C}$ before the temperature rose in the 1350 minute mark. In the last data collection, or in the 2100 minutes mark, the temperature of the fish in the coolbox showed a value of $23.9^{\circ} \mathrm{C}$,

while for the temperature of the fish in the Styrofoam coolbox showed the temperature right at $20{ }^{\circ} \mathrm{C}$.

In general, fish temperature testing is used as a parameter of whether or not fresh fish are stored in the coolbox. Because the fish in the coolbox is said to be fresh when the temperature is still below $20{ }^{\circ} \mathrm{C}$, the length of time for fish preservation is calculated when the temperature of the fish in the coolbox is below 20 ${ }^{\circ} \mathrm{C}$. Figure 10. showed that the styrofoam coolbox was able to maintain temperatures below $20{ }^{\circ} \mathrm{C}$ for 35 hours or 2100 minutes. Meanwhile, the composite coolbox time in maintaining the fish temperature below 20

${ }^{\circ} \mathrm{C}$ was 27.5 hours after the first data collection, or for 1650 minutes, equals $78,5 \%$ styrofoam coolbox preserve time. 


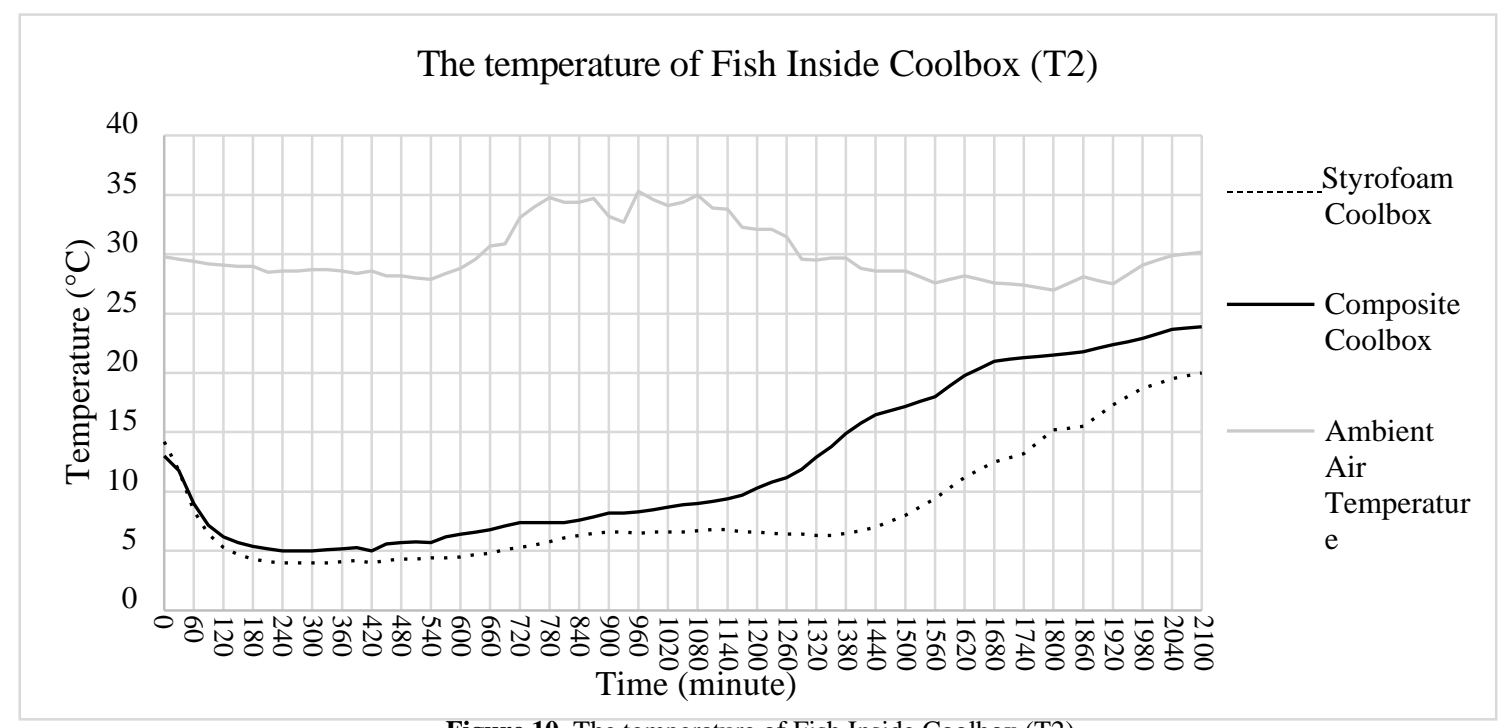

Figure 10. The temperature of Fish Inside Coolbox (T2)

Figure 11. shows the room temperature in the coolbox using sawdust of sengon wood and $\mathrm{KOH}-$ soaked coconut fiber and Styrofoam coolbox for 2100 minutes or 35 hours of observation. The initial room temperature in the composite coolbox started at 20.4 ${ }^{\circ} \mathrm{C}$, while the Styrofoam coolbox started at $23.3{ }^{\circ} \mathrm{C}$. Based on Figure 11, the initial temperature continued to decline due to the cooling process of the coolbox chamber by the ice just inserted. The reduction in the composite coolbox space lasted for 210 minutes since the first data collection and stopped at $17^{\circ} \mathrm{C}$. While the decrease in styrofoam coolbox room temperature lasted for up to 180 minutes, and the temperature drop stopped at $14.9^{\circ} \mathrm{C}$. It can be seen that both of room temperature of the coolbox starting from the 90th minute had a similar line up to the 930th minute with a relatively constant difference in temperature with an average difference of $2.8{ }^{\circ} \mathrm{C}$. Changes in the coolbox room temperature between minutes go hand in hand with changes in the external environment temperature, i.e., the temperature rose to 870 minutes, then dropped to 960 minutes for approximately $1{ }^{\circ} \mathrm{C}$ for both coolbox room temperatures. Coolbox composite temperature data rose again until the end of data retrieval and ended at $27{ }^{\circ} \mathrm{C}$. While the coolbox styrofoam room temperature dropped back to 1110 minutes to 1350 minutes at $1.6^{\circ} \mathrm{C}$ and then rose again until the end of the data collection with the thermocouple showed the coolbox styrofoam room temperature of $24.1^{\circ} \mathrm{C}$.

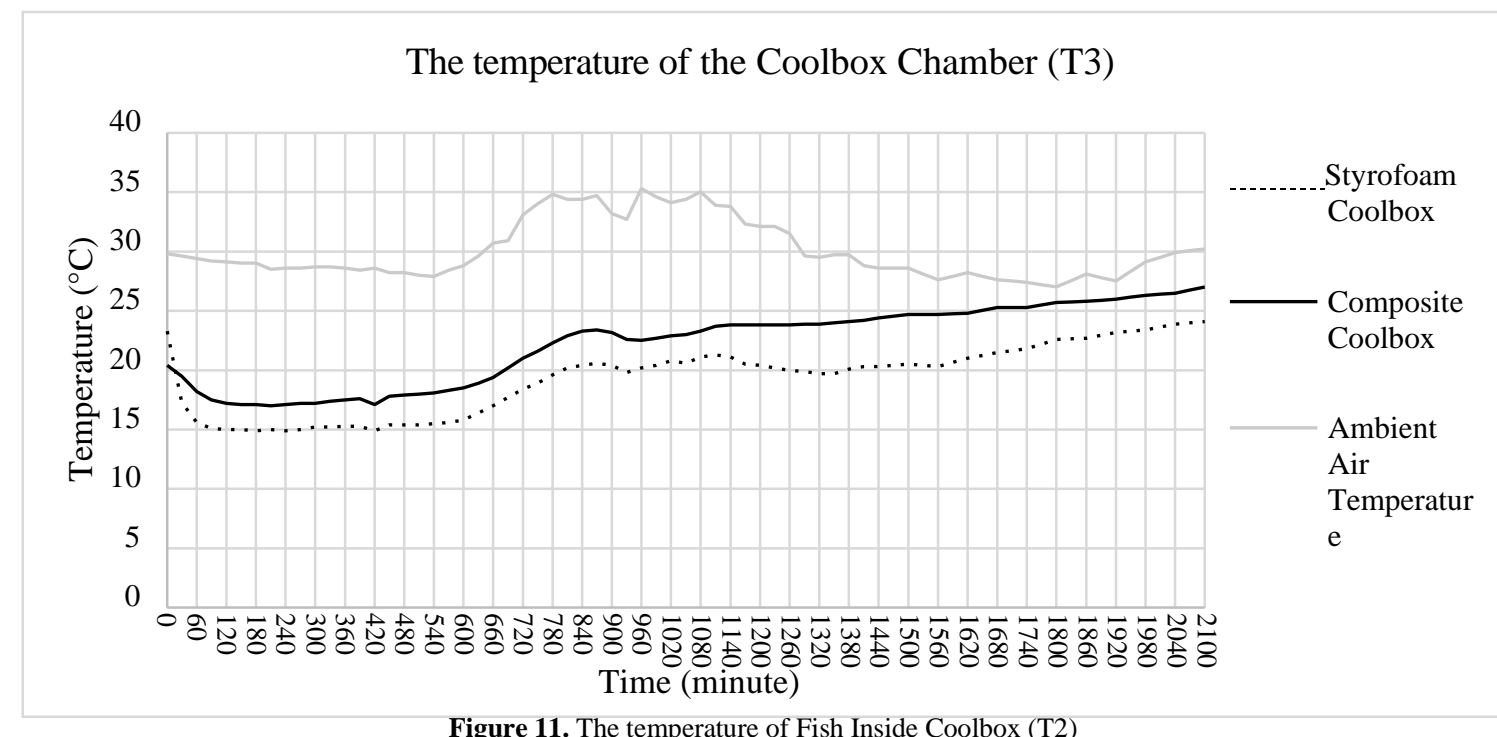

Figure 11. The temperature of Fish Inside Coolbox (T2) 


\section{CONCLUSION}

The best insulation using sengon wood sawdust and $\mathrm{KOH}$-soaked coconut coir has a composition of $30 \%$ sengon wood sawdust and $70 \% \mathrm{KOH}$-soaked coconut coir. The composite has the best thermal conductivity and density of $0.35229 \mathrm{~W} / \mathrm{mK}$, and $0.303 \mathrm{gram} / \mathrm{cm}^{3}$, with a specimen production cost of Rp607,00. from the coolbox test result, the minimum temperature coolbox could achieve was $0.3{ }^{\circ} \mathrm{C}$ at point 1 or below the wet ice surface in the first 150 minutes. At point 2 or inside the fish body, the lowest temperature achieved was $5^{\circ} \mathrm{C}$ in the first 240 minutes. In the coolbox chamber or point 3 , the lowest temperature achieved was $17{ }^{\circ} \mathrm{C}$ at the first 210 minutes. The results showed that the coolbox could preserve fish below $20{ }^{\circ} \mathrm{C}$ for 1650 minutes or

27.5 hours with a mass ratio of fish and ice 1:5, equal to $78,5 \%$ styrofoam coolbox preserve time with the same condition. So, for 24 hours of sailing for fishermen, the coolbox using sengon wood sawdust and $\mathrm{KOH}$ - soaked coconut coir could be a potential replacement for styrofoam coolbox in order to obtain more environmentally friendly coolbox as fish storage.

\section{REFERENCES}

[1] Sihombing, Puteri Ladika. 2018. Desain Kotak Pendingin pada Kapal Nelayan Tradisional menggunakan Insulasi Campuran Serbuk Gergaji Kayu Sengon (Paraserianthes Falcataria (L.) Nielsen) dan Jerami : Jurusan Teknik Sistem Perkapalan FTK - ITS.

[2] Badrawada, I, G, Gde., Susilo, A. 2009. Pengaruh Kepadatan Papan Partikel dari Tiga Jenis Serbuk Kayu Terhadap Nilai Konduktivitas Panasnya.

[3] Prasojo, A., Sulistyo, J., Listyanto, T., 2011. Konduktivitas Panas Empat Jenis Kayu dalam Kondisi Kadar Air yang Berbeda.

[4]Husein, Muhammad Azis. 2018. Analisis Penggunaan Serat Ijuk dan Sabut Kelapa Sebagai Insulator Ruang Muat Kapal Jenis Purse Seine : Jurusan Teknik Sistem Perkapalan FTK - ITS.

[5]Nasution, P., Fitri, S. P., \& Semin. 2014. Karakteristik Termofisik Komposit Sabut Kelapa Sebagai Insulator Pada Palka Ikan. Berkala Perikanan TerubukVol 42. No.2,82-92.

[6] Carrijo, O.A., Liz, R.S., Makishima, N. 2002. Fiber of Green Coconut shell as Agriculture substratum, Brazilian Horticulture, 20, 533-535.

[7] O. Faruk, Andrzej K. Bledzki, Hans-Peter Fink, Mohini Sain. 2012. Biocomposites Reinforced with Natural Fibers. Progress in Polymer Science 37 page 1552-1596.

[8] Alberto, Debi, dkk. 2015. Analisa Konduktivitas Thermal Material Komposit Serat Sabut Kelapa dengan Perlakuan Alkali dan Resin Poliester. Teknik Mesin Fakultas Teknologi Industri Universitas Bung Hatta.

[9] Pradana, M. A. 2017. Pemisahan Selulosa dari Lignin Serat Tandan Kosong Kelapa Sawit dengan Proses Alkalisasi untuk Penguat Bahan Komposit Penyerap Suara. Surabaya: Institut Teknologi Sepuluh Nopember

[10]Pratama, R. D., Farid, M., Nurdiansah, H. 2017. Pengaruh Proses Alkalisasi terhadap Morfologi Serat Tandan Kosong Kelapa Sawit untuk Bahan Penguat Komposit Absorbsi Suara.

[11] Sultoni, Yusuf. Moh. Farid, Alvian T. Wibisono. 2017. Pengaruh Proses Alkali dan Fraksi Massa Serat terhadap
Sifat Fisik dan Sifat Mekanik Komposit Polyurethane/Coir Fiber. Surabaya: Institut Teknologi Sepuluh Nopember

[12] Baheramsyah, Alam., Wardhana, Ede Mehta., Kisserah, Achmad Taufik Rendi. 2019. Utilization of Mixture of Teak Wood Sawdust and Bagasse Fiber using Treatment of Fiber Variations and Alkali $\mathrm{NaOH}$ Immersion as $\mathrm{A}$ Refrigerator Insulation Material. International Journal of Marine Engineering Innovation and Research 